\title{
TMEFF2 wt Allele
}

National Cancer Institute

\section{Source}

National Cancer Institute. TMEFF2 wt Allele. NCI Thesaurus. Code C162407.

Human TMEFF2 wild-type allele is located in the vicinity of 2 q32.3 and is approximately $247 \mathrm{~kb}$ in length. This allele, which encodes tomoregulin-2 protein, may be involved in neuronal cell survival. 